University for Business and Technology in Kosovo

UBT Knowledge Center

UBT International Conference

2016 UBT International Conference

Oct 28th, 9:00 AM - Oct 30th, 5:00 PM

\title{
Post disaster (war) rapid reconstruction and its impact on reducing living space at residential houses in Kosova
}

\author{
Lulzim Beqiri \\ University for Business and Technology, Ibeqiri@ubt-uni.net \\ Zejnulla Rexhepi \\ University for Business and Technology, zejnulla.rexhepi@ubt-uni.net \\ Mimoza Sylejmani \\ University for Business and Technology, mimoza.sylejmani@ubt-uni.net
}

Follow this and additional works at: https://knowledgecenter.ubt-uni.net/conference

Part of the Architecture Commons

\section{Recommended Citation}

Beqiri, Lulzim; Rexhepi, Zejnulla; and Sylejmani, Mimoza, "Post disaster (war) rapid reconstruction and its impact on reducing living space at residential houses in Kosova" (2016). UBT International Conference. 68.

https://knowledgecenter.ubt-uni.net/conference/2016/all-events/68

This Event is brought to you for free and open access by the Publication and Journals at UBT Knowledge Center. It has been accepted for inclusion in UBT International Conference by an authorized administrator of UBT Knowledge Center. For more information, please contact knowledge.center@ubt-uni.net. 
Post disaster (war) rapid reconstruction and its impact on reducing living space at residential houses in Kosova

\title{
Post disaster (war) rapid reconstruction and its impact on reducing living space at residential houses in Kosova
}

\author{
Lulzim Beqiri ${ }^{1}$, Zejnulla Rexhepi ${ }^{2}$, Mimoza Sylejmani ${ }^{2}$ \\ ${ }^{1,2}$ UBT - Higher Education Institution, Lagjja Kalabria, 10000 p.n., \\ Prishtine, Kosovo \\ $\left\{\right.$ lbeqiri $^{1}$; zejnulla.rexhepi ${ }^{2}$; mimoza.sylejmani $\left.{ }^{2}\right\} @$ ubt-uni.net
}

\begin{abstract}
Reconstruction process as a huge need after disaster, a part that is creating emergency shelter for people in need, as well has a direct impact on living space as one of the emergency created after every disaster. This paper aims to identify the impact of intervention of humanitarian organizations without being coordinated and agreed on minimal living standards that will be applicable during reconstruction phase because of environment created after disaster. Kosova was exposed to the war on 1998-1999 and massive destruction of 250000 residential houses (EAR 2000) and as result within several years after the war was over, the reconstruction took place being performed by different international and local organization in order to recover all damages in residential houses and creating emergency shelter for people in need. The reconstruction process was of benefit for Kosova that was not able to provide any assistance in the process of reconstruction but influenced reduction of living space by reducing comfort of people by transforming to the minimum living condition.
\end{abstract}

Keywords: Living space, reconstruction, disaster, comfort Process Engineering, Permit, optimization, time, cost, quality

There are two types of disaster based on factors that influence and initiate it as:

- Natural disaster

- Manmade disaster

The Natural disaster ((Tsunami, Tornados, Hurricanes (same as Tsunami), Cyclone (same as Tsunami), Flood, Snowstorm, Landslides, Drought, Earthquake, Electrical storms, Snow slides) are disaster due to forces of nature.

The Human - caused Disasters (Terrorism, Sabotage, Theft, Viruses, Worms, Hostile code, War, Theft, Arson, Loss of Power supply (both electric and gas), communications links, Data, Cyber-crime (many types)) are disasters caused by human.

There is no much to do or have impact on happening phenomena in natural disaster a part from to avoid or reduce their negative effect, comparing to human caused disaster that can be avoided through preventive approach, positive approach and some time on time reaction.

Focus of this paper will be reconstruction after manmade disaster in Kosovo War in Kosovo in 19981999 was human made disaster that, a part from human lives, destroyed a lot of building Kosovo wide. 


\section{Book of Proceedings \\ International Conference on Architecture and Spatial Planning}

It was a huge number of residential houses destroyed during this period, around 250000 (EAR report 2000) leaving 1 million of people without residential space.

\section{Residential house reconstruction}

Being in pressure of creating a sheltering program for over 1 million of inhabitants, international community tried to contribute through their organization (GO and NGO) and through different international agencies (UNHCR, UNICEF, UNDP etc.)

This paper aims to present how reconstruction reduces the commodity of living space through emergency reconstruction of residential houses, not because of luck of expertise, but because of emergency need for living space and because of lack of financial potential of resident to influence choice for their future living space.

During the 1999 conflict nearly half of Kosovo's 250,000 housing stock was damaged or destroyed. An assessment made in July 1999 by IMG on behalf of the European Commission indicated that 41,000 houses were partially damaged, 32,000 were seriously damaged (walls standing but roofs and interior burned), and 47,000 were completely destroyed (down to and often below the foundations). The houses of an estimated 500,000 people were badly damaged or destroyed, with these people consequently being made homeless. Emergency efforts by ECHO and other donors before the winter of 1999-2000 provided shelter for the worst affected families who could not move in with relatives. They were housed in partially repaired houses, temporary tents, pre-fabricated units, and collective centres. EC TAFKO commenced a major rehabilitation programme in 1999 to assist osovars in the rehabilitation of some 3,600 war damaged homes, and this was taken over by the Agency in 2000. (European Agency for econstruction Annual Report 2000 )

\section{Agency strategy}

The worst affected families, whose houses had been completely destroyed or which were without roofs, were given priority in accordance with the UNMIK Housing Reconstruction Guidelines. The latter had been developed in close collaboration with Agency staff, and ensured that the most vulnerable families received the appropriate assistance in relation to the amount of damage suffered. Kosovar participation in the programmes was facilitated by giving a lead role to the Municipal Housing Committees which had been specially established in the approved areas, by encouraging a 'self-help' approach with the beneficiaries, and by contracting local traders for the supply of materials. Local professionals and skilled laborers were also used by the EU NGOs which were responsible for the implementation of the program. ((European Agency for reconstruction Annual Report 2000)

All destroyed residential houses were categorized in 5 categories based on level of damage.

This categorization was done in following scale:

- House of category 1 (house with small damages as doors, windows and inside inventory)

- House of category 2 (houses with small damages as doors and windows, floor, inventory)

- House of category 3 (houses with small damages inside and outside building as some part of walls, small part of the roof but main construction still make possible to do repairs)

- House of category 4 (houses with considerable damages in walls, roof, floor, but still possible to me rebuild-repair in the same structure as main construction still remains in good shape and condition.

- $\quad$ House of category 5 (not repairable house) 
Post disaster (war) rapid reconstruction and its impact on reducing living space at residential houses in Kosova

\section{Reconstruction of category 5 houses}

Reconstruction of residential houses usually was not possible in the same place and in most of the cases not in the same size. After the disaster usually there is no economic potential of inhabitants to rebuild residential houses with same format and same commodity,

\section{Reconstruction - Case Study Istog}

As most of the cities and villages were destroyed during war, Istog as well was one of the most destroyed by all means, including residential houses as well. The municipal construction comity leaded by United Nation Mission in Kosova (UNMIK) organized a weekly meeting with all parties involved in residential houses reconstruction. Every Non-Government Organization-NGO and Government Organization GO that have been involved in reconstruction of category 5 houses were presenting to the comity which kind of houses they are going to reconstruct for local inhabitants.

As in the field have been operating many NGO-and GO reconstruction process was not under control referring to the size of living space and quality of building influenced by several factors as luck of professionals, luck of funds, lack of building materials in Kosova and a huge need of inhabitants for sheltering.

One of the NGO was Caritas Austria that did reconstruction of more than 250 houses in Istog and same number of houses in Prizren. The Author of this paper was engaged in whole project of reconstruction starting from design, materials, reconstruction and new construction of the residential houses.

The Caritas Austria managed to apply some standards in order not to provide big houses for small families and not a small houses for big families. In this regard, following standards have been approved: $12 \mathrm{~m}^{2}$ for every household and $8 \mathrm{~m}^{2}$ for every family member

- House for 1 person $-21.76 \mathrm{~m}^{2}(12+8=20)$

- $\quad$ House for 2 person $-32 \mathrm{~m}^{2}(12+16=28)$

- House for 3 person $-36 \mathrm{~m}^{2}(12+24=36)$

- House for 4 person $-45 \mathrm{~m}^{2}(12+32=44)$

- House for 5 person $-51 \mathrm{~m}^{2}(12+40=52)$

- House for 6 person $-60 \mathrm{~m}^{2}(12+48=60)$

- $\quad$ House for 7 person $-66.8 \mathrm{~m}^{2}(12+56=68)$

- $\quad$ House for 8 person $-76 \mathrm{~m}^{2}(12+64=76)$

- $\quad$ House for 9 person $-85 \mathrm{~m}^{2}(12+72=84)$

- House for 10 person $-92 \mathrm{~m}^{2}(12+80=92)$ 
Book of Proceedings

International Conference on Architecture and Spatial Planning

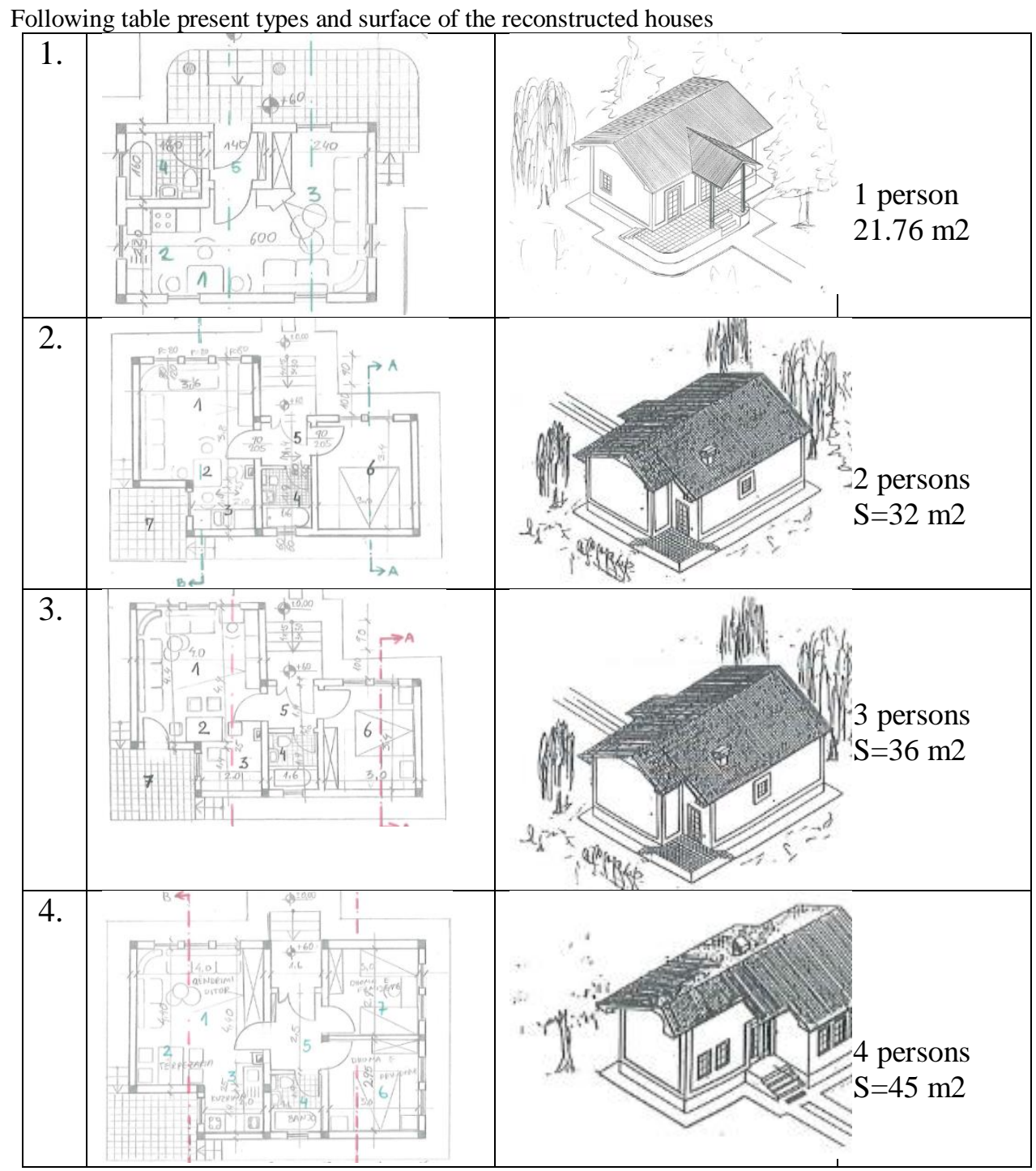


Post disaster (war) rapid reconstruction and its impact on reducing living space at residential houses in Kosova

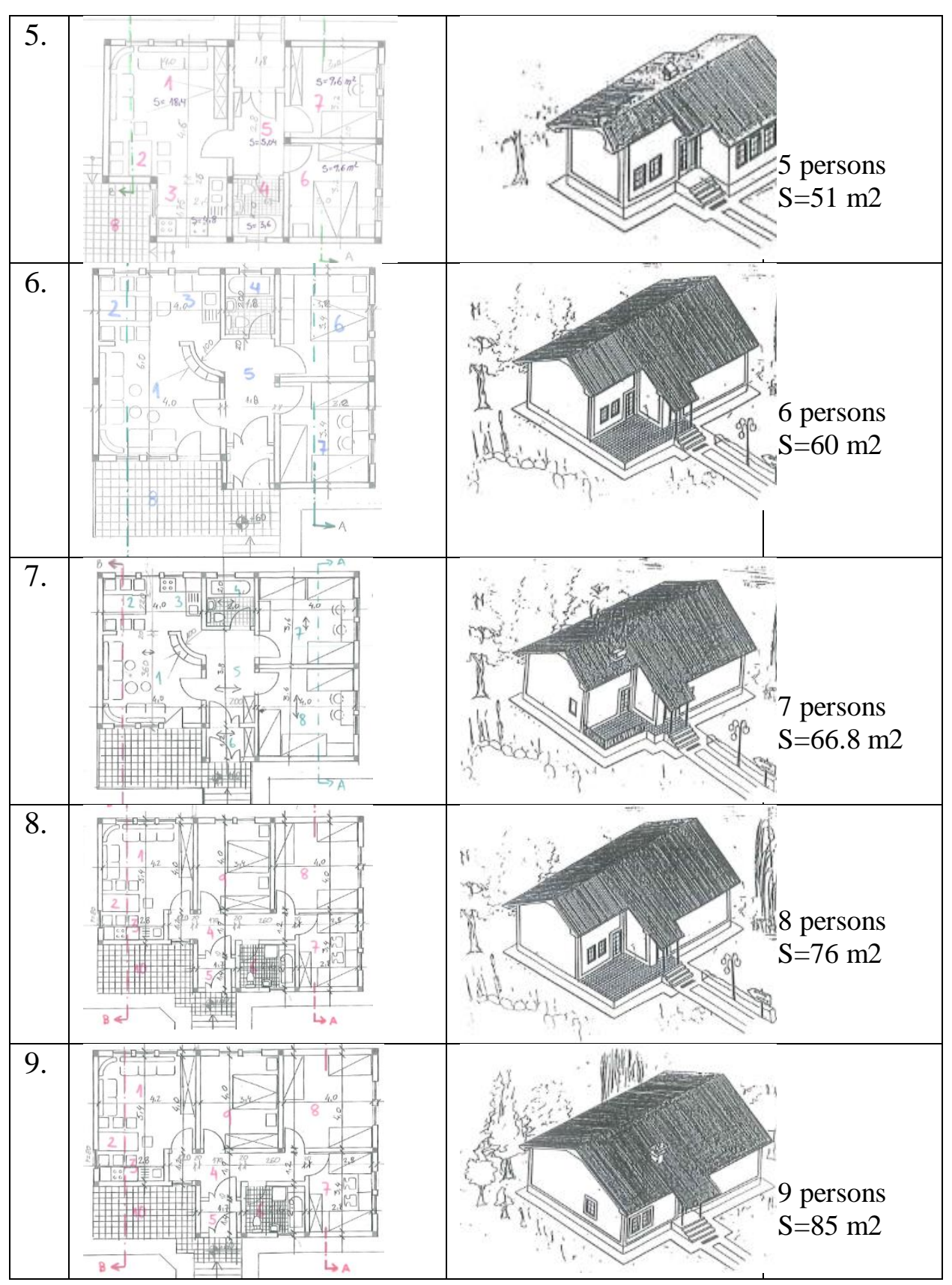


Book of Proceedings

International Conference on Architecture and Spatial Planning

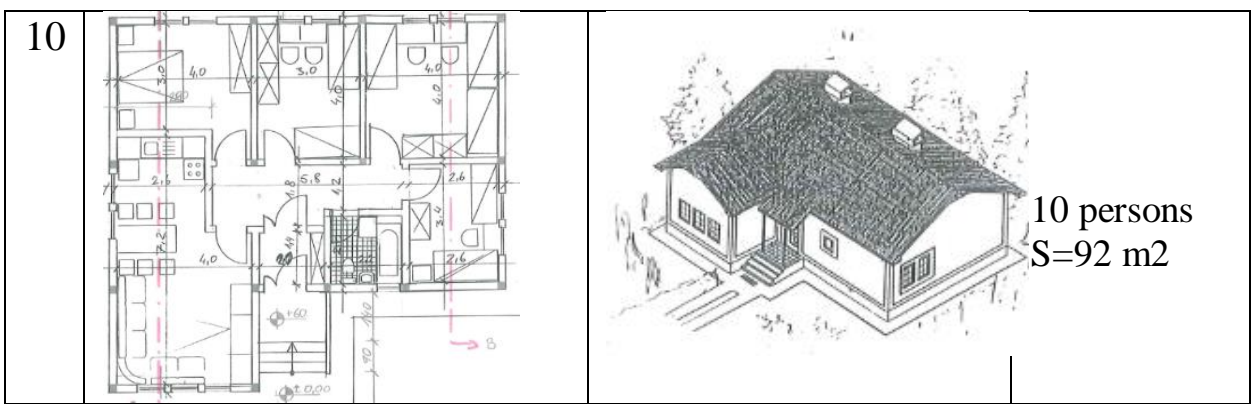

The above presented house models and size of the houses did not present, or have been equal to the surface of the destroyed houses. To some houses and families new reconstructed family house was half (some time even less than half) of surface of their destroyed house. Therefore in most of the cases reconstruction of destroyed houses reduced living space and commodity that family use to have before the war.

\section{PRISHTINA}

Another case study is surrounding of Prishtina and reconstruction of the houses shows the reduction of living space. Based on data taken from directorate of Urbanism in Prishtina following are date of categorization and surface destroyed during war.

Category I - 249 houses $(10.15 \%)$ with a total surface of $27,268.00 \mathrm{~m}^{2}$;

Category II - 308 house $(12.55 \%)$ with a total surface of $37,117.00 \mathrm{~m}^{2}$; Category III - 672 houses $(27.38 \%)$ with a total surface of $86,431.30 \mathrm{~m}^{2}$;

Category IV - 1225 houses (49.92\%) with a total surface of $127,235.00 \mathrm{~m}^{2}$;

Below table presents some beneficiaries the surface of rebuild houses -living space, based on number of family number, reconstructed houses had following size of living space.

- $\quad 50 \mathrm{~m}^{2}$

- $70 \mathrm{~m}^{2}$

- $75 \mathrm{~m}^{2}$

- $\quad 90 \mathrm{~m}^{2}$ 
Post disaster (war) rapid reconstruction and its impact on reducing living space at residential houses in Kosova

\begin{tabular}{|c|c|c|c|}
\hline No. & $\begin{array}{l}\text { Name/Surname } \quad \text { of } \\
\text { Household-owner }\end{array}$ & $\begin{array}{l}\text { Surface of the house } \\
\text { before reconstruction }\end{array}$ & $\begin{array}{l}\text { Surface of the house after } \\
\text { reconstruction }\end{array}$ \\
\hline & & $\mathrm{m}^{2}$ & $\mathrm{~m}^{2}$ \\
\hline 1 & Hazir Ramiz Haziri & 230 & 69 \\
\hline 2 & Ramiz Zejnullah Ajeti & 182 & 73 \\
\hline 3 & Ragip Zejnullah Ajeti & 182 & 73 \\
\hline 4 & Hamza Shaban Emini & 215 & 90 \\
\hline 5 & Nexhmedin Emini & 225 & 90 \\
\hline 6 & Hashim Shabani & 155 & 50 \\
\hline 7 & Safet Ragipi & 140 & 50 \\
\hline 8 & Jalil Muharrem Sokoli & 250 & 70 \\
\hline 9 & Izaur Ismaili & 320 & 75 \\
\hline 10 & Ruvije Nebesaqa & 150 & 50 \\
\hline 11 & Xhemajl Dalipi & 200 & 74 \\
\hline 12 & Shahe Krasniqi & 265 & 75 \\
\hline 13 & Sabile Kongjeli & 270 & 75 \\
\hline & & 2784 & 914 \\
\hline & \multicolumn{2}{|c|}{ Reduction ratio of comfort expressed in $\mathrm{m}^{2}$} & 1870 \\
\hline & \multicolumn{2}{|c|}{ The reduction ratio of comfort expressed in percentage } & $67 \%$ \\
\hline
\end{tabular}

\section{Conclusion}

Above analyses shows that after every disaster, reconstruction usually brings reduction of the living spaces and commodity of inhabitants.

Considering very important, Household being I harry to rebuild their resident houses needs to closely cooperate with donor community, local and central government that create strategy (emergency strategy) for application of existing standards related to living space of the country, or international standards, and create possibility for further extension of the residential building.

The reconstruction process, as very necessary, after every human caused disaster, respectively in cases of governance change, the donor community should be leaded by group of experts that will create a roadmap and clear reconstruction standards based on local standards, if exist, or apply standards that 
Book of Proceedings

International Conference on Architecture and Spatial Planning

make possible to household for recovering their living space and create good basement for future recovery of their commodity that they had, and lost, during disaster.

Not only reconstruct what was destroyed, but to be considered rebuild a houses in a format that can integrate modern concept of energy efficiency by using local materials and concept, and just if necessary import building material that cannot found in the region.

\section{References:}

1.

2. European Agency for Reconstruction Annual Report 2000; 28/2/2001

3. European Agency for Reconstruction Annual Report 2000;19/04/2002

4. Report of the Secretary-General on the United Nations Interim Administration Mission in Kosovo; 6 June 2000

5. Report of the Secretary-General on the United Nations Interim Administration Mission in Kosovo; 18 September 2000

6. Report of the Secretary-General on the United Nations Interim Administration Mission in Kosovo; 15 December 2000

7. Report of the Secretary-General on the United Nations Interim Administration Mission in Kosovo; 13 March 2001

8. Report of the Secretary-General on the United Nations Interim Administration Mission in Kosovo; 7 June 2001

9. Report of the Secretary-General on the United Nations Interim Administration Mission in Kosovo; 2 October 2001

10. Sabine Wartha-Caritas Austria-wienna.

11. Directorate of Urbanism, Municipality of Prishtina, Prishtina Kosovo 